Article

\title{
Copper Complexes with Tetradentate Ligands for Enhanced Charge Transport in Dye-Sensitized Solar Cells
}

\author{
Hannes Michaels ${ }^{1}$, Iacopo Benesperi ${ }^{1}$ (i) , Tomas Edvinsson ${ }^{2}$, Ana Belén Muñoz-Garcia ${ }^{3}$, \\ Michele Pavone ${ }^{4}$, Gerrit Boschloo ${ }^{1}$ (D) and Marina Freitag ${ }^{1, *}$ \\ 1 Department of Chemistry, Ångström Laboratory, Uppsala University, P.O. Box 523, \\ SE-75120 Uppsala, Sweden; hannes.michaels@kemi.uu.se (H.M.); iacopo.benesperi@kemi.uu.se (I.B.); \\ gerrit.boschloo@kemi.uu.se (G.B.) \\ 2 Department of Solid-state Physics, Ångström Laboratory, Uppsala University, P.O. Box 534, \\ SE-75121 Uppsala, Sweden; Tomas.Edvinsson@angstrom.uu.se \\ 3 Department of Physics "Ettore Pancini", University of Naples Federico II, 80126 Naples, Italy; \\ anabelen.munozgarcia@unina.it \\ 4 Department of Chemical Sciences, University of Naples Federico II, 80126 Naples, Italy; \\ michele.pavone@unina.it \\ * Correspondence: marina.freitag@kemi.uu.se
}

Received: 28 April 2018; Accepted: 16 May 2018; Published: 21 May 2018 updates

\begin{abstract}
In dye-sensitized solar cells (DSCs), the redox mediator is responsible for the regeneration of the oxidized dye and for the hole transport towards the cathode. Here, we introduce new copper complexes with tetradentate 6,6'-bis(4-(S)-isopropyl-2-oxazolinyl)-2,2'-bipyridine ligands, $\mathrm{Cu}$ (oxabpy), as redox mediators. Copper coordination complexes with a square-planar geometry show low reorganization energies and thus introduce smaller losses in photovoltage. Slow recombination kinetics of excited electrons between the $\mathrm{TiO}_{2}$ and $\mathrm{Cu}^{\mathrm{II}}$ (oxabpy) species lead to an exceptionally long electron lifetime, a high Fermi level in the $\mathrm{TiO}_{2}$, and a high photovoltage of $920 \mathrm{mV}$ with photocurrents of $10 \mathrm{~mA} \cdot \mathrm{cm}^{-2}$ and $6.2 \%$ power conversion efficiency. Meanwhile, a large driving force remains for the dye regeneration of the Y123 dye with high efficiencies. The square-planar $\mathrm{Cu}$ (oxabpy) complexes yield viscous gel-like solutions. The unique charge transport characteristics are attributed to a superposition of diffusion and electronic conduction. An enhancement in charge transport performance of $70 \%$ despite the higher viscosity is observed upon comparison of $\mathrm{Cu}$ (oxabpy) to the previously reported $\mathrm{Cu}(\mathrm{tmby})_{2}$ redox electrolyte.
\end{abstract}

Keywords: dye-sensitized solar cell; solar cell; copper complex; redox mediator; electrolyte; tetradentate

\section{Introduction}

A steep incline in energy demands, paired with an increased awareness of climate change, has driven the development of renewable energy sources [1]. Technologies for harvesting solar energy have evolved and photovoltaics has become a major focus in today's politics and research. Dye-sensitized solar cells (DSCs), as first described by Gerischer [2] and implemented by Grätzel [3], provide a low-cost alternative for large-scale solar energy conversion based on inexpensive and Earth-abundant materials [4-6]. Since the beginning of DSC development in 1991, impressive power conversion efficiencies above $14 \%$ have been demonstrated [7]. Light absorption in a DSC is based on dye molecules anchored to a porous metal oxide semiconductor (typically $\mathrm{TiO}_{2}$, Figure 1a). Photon absorption leads to injection of electrons from the excited dye molecules $\left(D^{*}\right)$ into the conduction band of the semiconductor and subsequently an external circuit, while the dye 
is regenerated by a redox electrolyte. Crucial photovoltaic parameters of solar cells include the photocurrent, determined by light absorption and carrier injection by the dye, and the photovoltage, largely dependent on the molecular engineering of the redox mediators. Initially, the iodide-triiodide redox couple played an important role in the electrolyte development [8]. The $\mathrm{I}^{-} / \mathrm{I}_{3}{ }^{-}$electrolyte allows high photocurrents by reducing recombination losses [9]. However, it also carries drawbacks such as potential drops and competitive light absorption [10,11]. In 2010, Feldt et al. demonstrated high-efficiency DSCs with $\mathrm{Co}^{\mathrm{II} / \mathrm{III}}(\mathrm{bpy})_{3}$ as redox mediators [12]. Upon further investigation, however, deficient diffusion through the mesoporous $\mathrm{TiO}_{2}$ layer limited the photovoltaic performance of these bulky octahedral tris-bipyridine-based cobalt mediators [13-15]. Furthermore, cobalt complexes showed limited stability especially under irradiative conditions due to e.g., ligand exchanges, impeding their potential for large-scale applications [16]. $\mathrm{Cu}^{\mathrm{I} / \mathrm{II}}$-based redox shuttles emerged as premiere high-performing, tunable redox mediators and stand out through straightforward synthetic paths and high photovoltages based on low-cost materials. Hattori et al. introduced for the first time bis(2,9-dimethyl-1,10-phenanthroline)copper(I/II) complexes as redox mediators with $1.4 \%$ power conversion efficiency (PCE) [17]. Consecutively, PCEs of 7\% with the C218 dye were achieved by Bai et al. And a 8.3\% PCE was presented by Freitag et al. with the organic D- $\pi$-A dye LEG4 $[18,19]$. The mark of $10 \%$ PCE was surpassed for copper-based DSCs when Saygili et al. introduced copper bipyridyl redox mediators in 2016 [20]. Recent results present improved PCEs up to 11.7\% [21,22].

DSCs, however, carry a disadvantage in the usage of liquid volatile electrolytes. Difficulties concerning encapsulation have thus far impeded the commercial production of DSCs. Therefore, the development of electrolytes with higher viscosity shows higher potential for commercialization [23]. Furthermore, solid-state hole transport materials (HTMs) evolved as solvent-free hole transport materials based on organic hole conductors as well as metal complexes [24,25].

Reorganization energies upon changes of oxidation state are one reason for performance losses in DSCs mediated by metal complexes [26-28]. In previously reported approaches, this reorganization was prevented by ligands with sterically hindering groups to suppress coordination changes upon charging/discharging $[18,20]$.

(a)

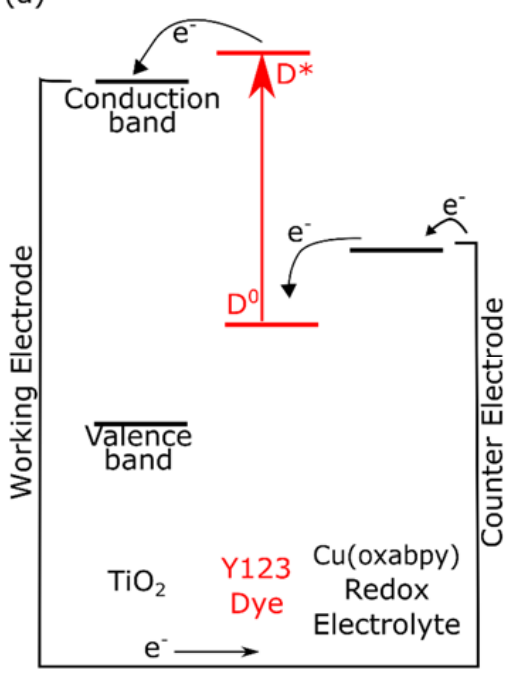

(b)

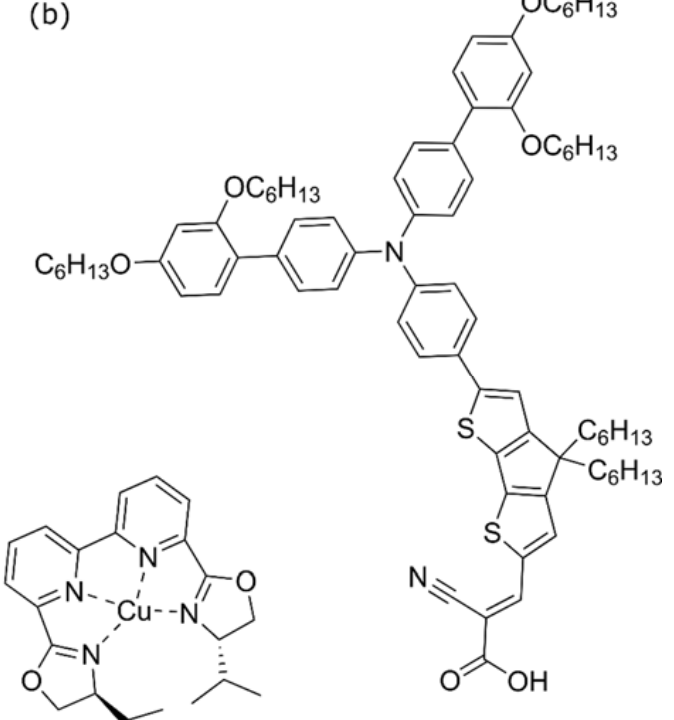

Figure 1. (a) Schematic diagram of charge transport processes in a Dye-sensitized Solar Cell (DSC). (b) Chemical structures of the Cu(oxabpy) complex (left) and the Y123 dye (right). One or two bis(trifluoromethane)sulfonimide (TFSI) ions (not shown) serve as counter-ions for the $\mathrm{Cu}^{\mathrm{I}}$ - and $\mathrm{Cu}^{\mathrm{II}}$-based complexes, respectively. 
In the present work, we report a copper(I/II) redox couple with a tetradentate (6,6'-bis(4-(S)-isopropyl-2-oxazolinyl)-2,2'-bipyridine) ligand, $\mathrm{Cu}^{\mathrm{I} / \mathrm{II}}$ (oxabpy) (Figure 1b). Linking all four coordination sites into one ligand molecule greatly reduces geometry re-arrangements between different copper oxidation states, compared to mono- or bidentate ligands [29,30]. Therefore, charges can be mediated in the $\mathrm{Cu}$ (oxabpy) redox electrolyte more rapidly and with fewer potential losses. In addition to smaller geometry rearrangements, the tetradentate ligand also impedes ligand exchange or loss processes [31]. Low absorption coefficients in the visible range render competitive light absorption negligible. Recombinative charge transfer of electrons from the $\mathrm{TiO}_{2}$ to the $\mathrm{Cu}^{\mathrm{II}}$ species is largely suppressed for the $\mathrm{Cu}$ (oxabpy) electrolyte, leading to a high Fermi level in the $\mathrm{TiO}_{2}$. Therefore, open-circuit potentials of $920 \mathrm{mV}, 9.75 \mathrm{~mA} \cdot \mathrm{cm}^{-2}$ photocurrent and $6.2 \%$ PCE were reached in Y123-sensitized DSCs despite the comparatively low redox potential ( $0.66 \mathrm{~V}$ vs. normal hydrogen electrode (NHE)) compared to previously reported Cu-based redox mediators [20]. Furthermore, the square planar coordination geometry of $\mathrm{Cu}$ (oxabpy) complexes enables superior charge transport properties. $\mathrm{Cu}$ (oxabpy) electrolytes exhibit a more than 2.5 times higher viscosity relative to the previously reported $\mathrm{Cu}(\mathrm{tmby})_{2}$ redox system. Nonetheless, the $\mathrm{Cu}$ (oxabpy) electrolyte shows a 1.6 times higher conductivity at similar bias potentials.

\section{Results and Discussion}

\subsection{Characterization of $\mathrm{Cu}($ oxabpy) Complexes}

Absorption and photoluminescence spectra of $\mathrm{Cu}^{\mathrm{I} / \mathrm{II}}$ (oxabpy) complexes are shown in Figure 2. Absorption and photoluminescence maxima as well as extinction coefficients are tabulated together with the formal redox potential in Table 1. The redox potential was obtained through the cyclic voltammogram of the $\mathrm{Cu}^{\mathrm{I}}$ (oxabpy) complex (see Figure S1).

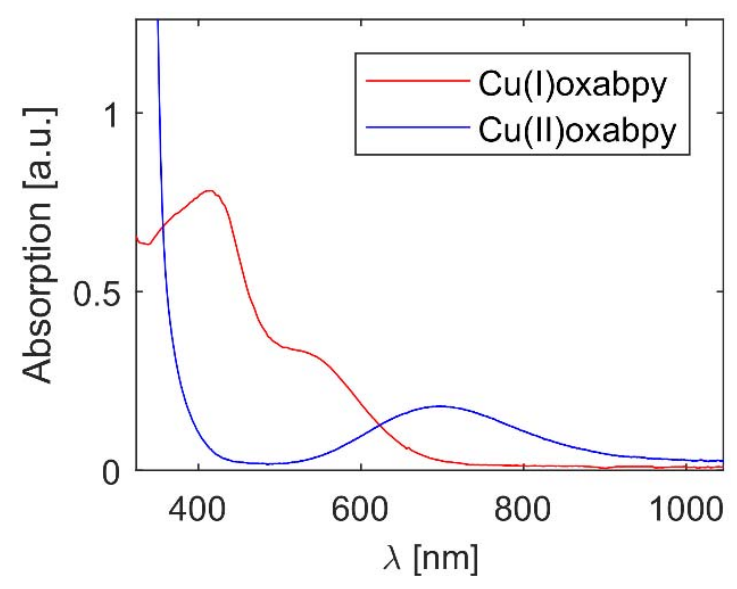

Figure 2. Absorption spectra (solid lines) of $\mathrm{Cu}^{\mathrm{I}}$ (oxabpy) (red) and $\mathrm{Cu}^{\mathrm{II}}$ (oxabpy) (blue).

Table 1. Optical and Electrochemical Characteristics of $\mathrm{Cu}^{\mathrm{I} / \mathrm{II}}$ (oxabpy) Complexes.

\begin{tabular}{cccc}
\hline Compound & $\mathrm{E}_{\text {redox }}(\mathbf{V}$ vs. NHE) & $\lambda_{\text {max,abs }}(\mathbf{n m})$ & $\varepsilon\left(\mathbf{M}^{-\mathbf{1}} \mathbf{c m}^{\mathbf{- 1}}\right)$ \\
\hline $\mathrm{Cu}^{\mathrm{I}}$ (oxabpy)TFSI & \multirow{2}{*}{$0.66^{*}$} & 415 & 1587 \\
$\mathrm{Cu}^{\mathrm{II}}$ (oxabpy)TFSI & & 697 & 93 \\
\hline
\end{tabular}

* The formal potential $\mathrm{E}^{0^{\prime}}$ of the redox system was determined from anodic and cathodic current peaks in the cyclic voltammogramm of the $\mathrm{Cu}^{\mathrm{I}}$ species (see Figure $\mathrm{S} 1$ ).

The optical absorption spectrum of $\mathrm{Cu}^{\mathrm{I}}$ (oxabpy) shows a first optical transition associated with the HOMO-LUMO transition around $520 \mathrm{~nm}$. This is confirmed by the calculated weak oscillator strength for the first vertical transition computed with time-dependent DFT (TD-DFT) (see below for 
computational details, corresponding data are listed in Table S1). The absorption maximum at $415 \mathrm{~nm}$ is attributed to excitation of electrons from the HOMO - 2 to the LUMO (Figure S5). The oscillator strength for this transition is calculated to be two orders of magnitude higher than for the first transition. An extinction coefficient of $1587 \mathrm{M}^{-1} \mathrm{~cm}^{-1}$ was measured for $\mathrm{Cu}$ (oxabpy) and negligible absorption was observed around $700 \mathrm{~nm}$ for the $\mathrm{Cu}^{\mathrm{II}}$ (oxabpy). Therefore, the Cu(oxabpy) electrolyte competes for light absorption significantly less than previously introduced $\mathrm{Cu}$-based electrolytes (e.g., $5300 \mathrm{M}^{-1} \mathrm{~cm}^{-1}$ for $\left.\mathrm{Cu}^{\mathrm{I}}(\mathrm{tmby})_{2}\right)$ [20].

The formal potential of the $\mathrm{Cu}$ (oxabpy) redox system is found at $0.66 \mathrm{~V}$ vs. NHE. It is thus situated significantly lower compared to previously reported Cu-based redox electrolytes (e.g., $0.87 \mathrm{~V}$ for $\left.\mathrm{Cu}(\mathrm{tmby})_{2}\right)$ [20].

Electrolyte solutions with the $\mathrm{Cu}^{\mathrm{I} / \mathrm{II}}$ (oxabpy) redox couple were gel-like in appearance. To study the gelation of $\mathrm{Cu}$ (oxabpy) complexes, viscosity measurements were conducted for $\mathrm{Cu}(\mathrm{oxabpy})$ with respect to the $\mathrm{Cu}$ (tmby) 2 redox system in $\mathrm{Cu}^{\mathrm{I}}$ 5:1 $\mathrm{Cu}^{\mathrm{II}}$ composition (as in the electrolyte). The flow speed through a capillary measured with a ViscoClock showed that the addition of $\mathrm{Cu}(\mathrm{oxabpy})$ complexes to chloroform lead to a 2.6 times greater increase of the solution viscosity compared to the addition of an equal amount of the $\mathrm{Cu}(\mathrm{tmby})_{2}$ couple (see Figure $\mathrm{S} 2$ ).

Raman spectra of $\mathrm{Cu}^{\mathrm{I} / \mathrm{II}}$ (oxabpy) complexes are shown in Figure 3.

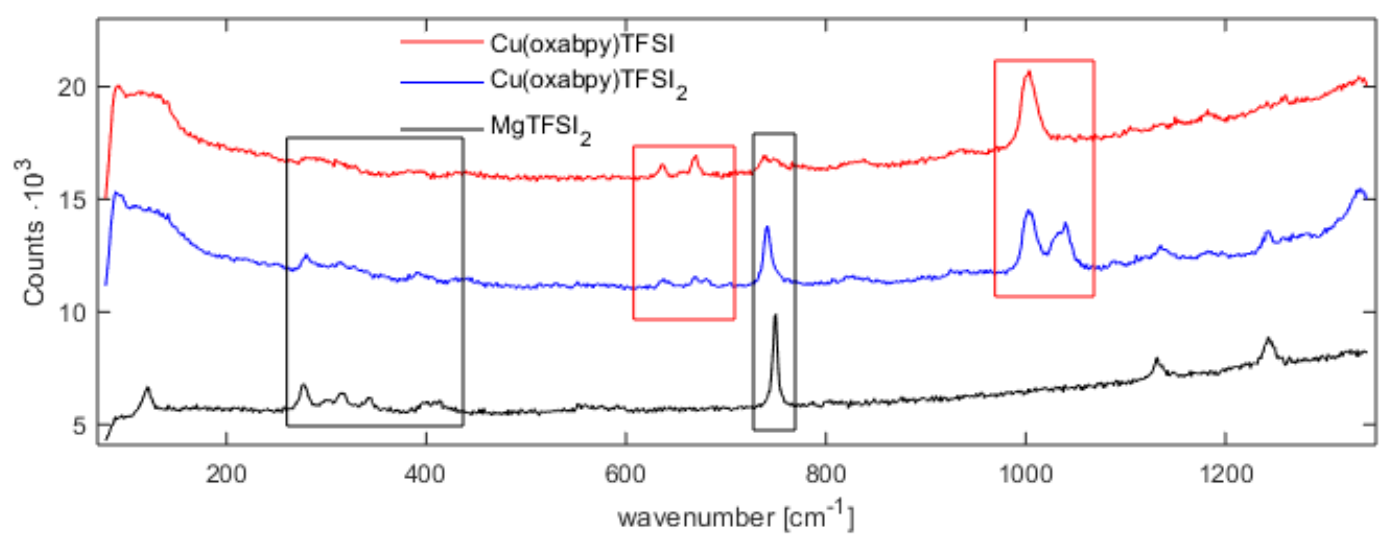

Figure 3. Raman spectra of $\mathrm{Cu}$ (oxabpy)TFSI, $\mathrm{Cu}$ (oxabpy)TFSI 2 and $\mathrm{MgTFSI}_{2}$. For clarity, the $\mathrm{Cu}^{\mathrm{I}}$ and $\mathrm{Cu}^{\mathrm{II}}$ spectra were offset by $8 \times 10^{3}$ and $11 \times 10^{3}$ counts, respectively. Black boxes highlight Raman modes of the TFSI counterion, red dashed boxes mark modes of the complex.

Modes between $250 \mathrm{~cm}^{-1}$ and $410 \mathrm{~cm}^{-1}$ as well as at $749 \mathrm{~cm}^{-1}$ in the spectra of $\mathrm{Cu}$ (oxabpy)TFSI and $\mathrm{Cu}$ (oxabpy)TFSI 2 were identified to origin from the TFSI counterion (black boxes). Furthermore, features at $1131 \mathrm{~cm}^{-1}$ and $1247 \mathrm{~cm}^{-1}$ were associated with the TFSI counterion. The TFSI modes are generally found in higher relative intensity for the $\mathrm{Cu}^{\mathrm{II}}$ (oxabpy) compared to the $\mathrm{Cu}^{\mathrm{I}}$ (oxabpy), confirming the presence of two TFSI counterions for the $\mathrm{Cu}^{\mathrm{II}}$ (oxabpy) complex. The Cu${ }^{\mathrm{II}}$ (oxabpy) complex shows strong modes at $1003 \mathrm{~cm}^{-1}$ and $1040 \mathrm{~cm}^{-1}$, which can be affiliated with a C-N stretch and a pyridine breathing mode as previously reported for similar compounds [32]. The breathing mode, however, is not visible in the spectrum of $\mathrm{Cu}^{\mathrm{I}}$ (oxabpy). This is attributed to the longer bond to the copper metal center (see Figure 4), which impedes this vibration and serves as a strong signature to distinguish the coordination of $\mathrm{Cu}^{\mathrm{I}}$ or $\mathrm{Cu} \mathrm{u}^{\mathrm{II}}$ to the pyridine nitrogen. Additional modes at $630 \mathrm{~cm}^{-1}$ and $668 / 680 \mathrm{~cm}^{-1}$ in the $\mathrm{Cu}^{\mathrm{I} / \mathrm{II}}$ (oxabpy) complexes are attributed to the oxazoline units. A pair of bands arises at $668 / 680 \mathrm{~cm}^{-1}$ upon coordination in $\mathrm{Cu}^{\mathrm{II}}$ (oxabpy), while the vibration at $680 \mathrm{~cm}^{-1}$ is again not visible in $\mathrm{Cu}^{\mathrm{I}}$ (oxabpy). 


\subsection{Density Functional Theory Calculations}

In order to estimate the reaction-free energies and internal reorganization energies for the $\mathrm{Cu}^{\mathrm{I} / \mathrm{II}}$ (oxabpy) complexes, DFT calculations with the Gaussian 16 suite of programs [33] were performed at the B3LYP-D3B [34] level of theory [34-36], with SDD as basis set for $\mathrm{Cu}$ and 6-31++G(d,p) basis set for other atoms. Structural optimizations, molecular frequencies, and thermochemistry data have been computed in acetonitrile by applying the polarizable continuum model (PCM) for the solvent degrees of freedom [37]. Vertical excitation energies for the $\mathrm{Cu}^{\mathrm{I} / \mathrm{II}}$ (oxabpy) complexes have been computed on the minimum energy structures with time-dependent DFT (TD-DFT) by applying the same level of theory and solvent model [38].

The minimum-energy structures of $\mathrm{Cu}^{\mathrm{I} / \mathrm{II}}$ (oxabpy) complexes are shown in Figure 4 .
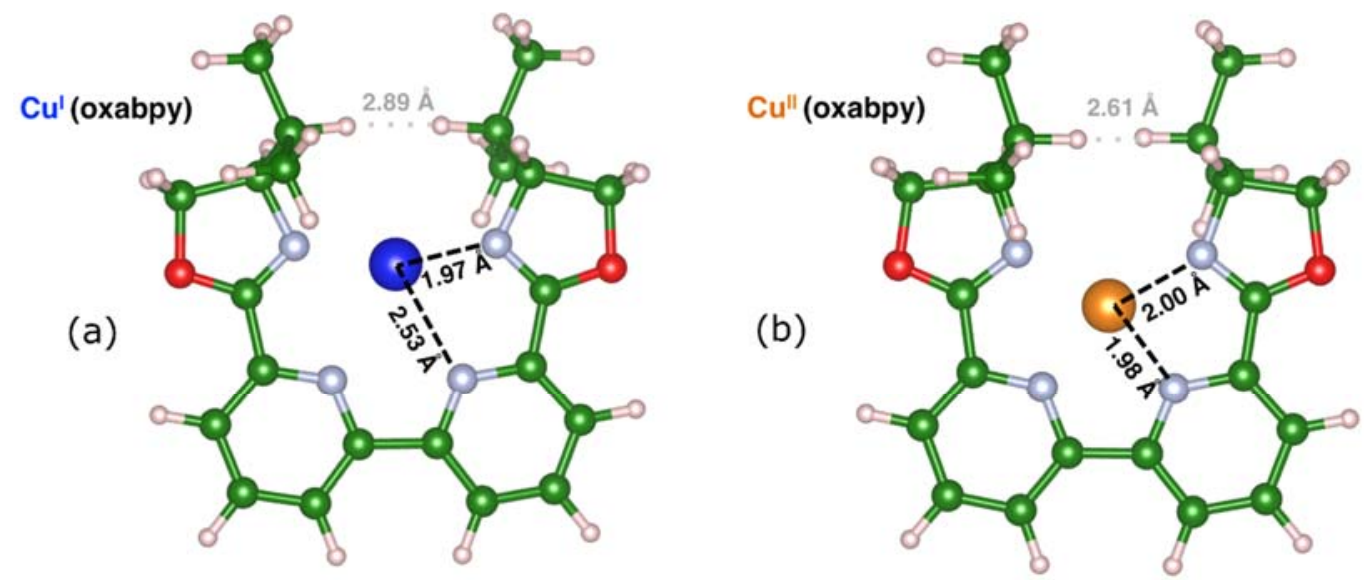

(c)
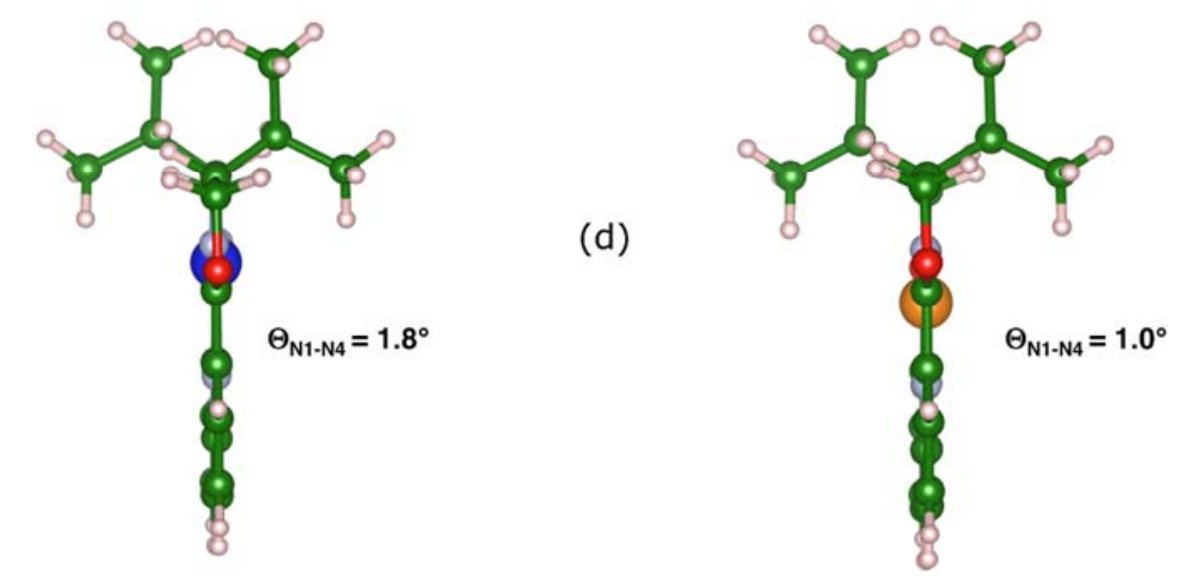

Figure 4. $\mathrm{Cu}^{\mathrm{I}}$ (oxabpy) $(\mathbf{a}, \mathbf{c})$ and $\mathrm{Cu}^{\mathrm{II}}$ (oxabpy) $(\mathbf{b}, \mathbf{d})$ minimum-energy structures calculated at the DFT / B3LYP-D3BJ level of theory in acetonitrile (PCM). (a,b): top view. Non-equivalent $\mathrm{Cu}-\mathrm{N}$ distances (black dashed lines) and distances between germinal $\mathrm{H}$ of terminal isopropyl groups (grey dotted lines) are indicated. $(\mathbf{c}, \mathbf{d})$ : lateral view. Dihedral angles of each $\mathrm{N} 1-\mathrm{N} 2-\mathrm{N} 3-\mathrm{N} 4$ plane $\left(\Theta_{\mathrm{N} 1-\mathrm{N} 4}\right)$ are indicated.

From analysis of DFT minimum energy geometries for $\mathrm{Cu}^{\mathrm{I}}$ and $\mathrm{Cu}^{\mathrm{II}}$ complexes, the most evident feature is the significant shift of the copper position upon oxidation from $\mathrm{Cu}^{\mathrm{I}}$ to $\mathrm{Cu}^{\mathrm{II}}$. While both $\mathrm{Cu}^{\mathrm{I}}$ and $\mathrm{Cu}^{\mathrm{II}}$ complexes have a planar configuration of the $\mathrm{N} 4$ open ring, the coordination of $\mathrm{Cu}^{\mathrm{I}}$ tends to involve only the two nitrogen atoms in the oxazoline groups in a quasi linear geometry $(\mathrm{Cu}-\mathrm{N}$ distances are reported in Figure 4). In the $\mathrm{Cu}^{\mathrm{II}}$ complex the copper atom is accommodated in a planar square configuration with the four nitrogen atoms with about $2.0 \AA$ A of distance. Moreover, the N4 pseudo-ring appears to be more open by $\sim 10 \%$ in the case of $\mathrm{Cu}^{\mathrm{I}}$ than in the $\mathrm{Cu}^{\mathrm{II}}$ one. These coordination differences have a direct consequence on the computed spectroscopic properties of the complexes, in agreement 
with the observed experimental differences between the Raman spectra of $\mathrm{Cu}^{\mathrm{I}} / \mathrm{Cu}^{\mathrm{II}}$ complexes (see Figure 3). Quenching of the pyridine breathing vibration at $1247 \mathrm{~cm}^{-1}$ for the $\mathrm{Cu}^{\mathrm{I}}$ (oxabpy) complex proves the alteration of the metal-ligand bonding with respect to $\mathrm{Cu}^{\mathrm{II}}$ (oxabpy). Therefore, the change in bond lengths as suggested by DFT calculations is confirmed.

To study the stability of $\mathrm{Cu}^{\mathrm{I}} / \mathrm{Cu}^{\mathrm{II}}$ (oxabpy) complexes and the possibility of an additional coordination of a TFSI counterion, we first considered the binding between $\mathrm{Cu}^{\mathrm{I}} / \mathrm{Cu}^{\mathrm{II}}$ species and the (oxabpy) ligand. Total binding energies have been computed as total energy differences between the complexes and the isolated species (including zero-point vibrational energies). For the $\mathrm{Cu}^{\mathrm{I}} / \mathrm{Cu}^{\mathrm{II}}$ (oxabpy) complexes the computed values are -3.27 and $-8.20 \mathrm{eV}$ for $\mathrm{Cu}^{\mathrm{I}}$ and $\mathrm{Cu}^{\mathrm{II}}$, respectively. The negative values mean that the formation of these complexes is favorable. When adding a TFSI anion to these systems, we considered the interaction between its $\mathrm{N}$ atom and the copper, forming a pseudo-square pyramid coordination with the $\mathrm{Cu} \mathrm{u}^{\mathrm{I} / \mathrm{II}}$ (see Figure S3-S4). In these new complexes the computed binding energies become -3.54 and $-8.77 \mathrm{eV}$ for $\mathrm{Cu}^{\mathrm{I}}$ and $\mathrm{Cu}^{\mathrm{II}}$, respectively. The TFSI alone provides an extra stabilization of -0.27 and $-0.57 \mathrm{eV}$ for $\mathrm{Cu}^{\mathrm{I}}$ and $\mathrm{Cu}^{\mathrm{II}}$ complexes, respectively.

From these data we obtain that the $\mathrm{Cu}^{\mathrm{II}}$ interacts more strongly with the ligand, probably due to the more efficient coordination of all the four $\mathrm{N}$ atoms of the oxabpy ligand. The favorable interaction with TFSI is mostly due to classic electrostatics, as a matter of facts the TFSI does not alter the nature and the shape of the frontier orbitals (as shown for the HOMO in Figure S4). These results highlight the importance of considering also the possibility of other co-ligands for the $\mathrm{Cu}{ }^{\mathrm{I} / \mathrm{II}}$ (oxabpy) complexes, paving the route to further studies in this direction.

\subsection{Photovoltaic Performance in Dye-Sensitized Solar Cells}

Photovoltaic data of Y123-sensitized solar cells fabricated with the $\mathrm{Cu}$ (oxabpy) and $\mathrm{Cu}(\mathrm{tmby})_{2}$ redox couples are shown in Figure 5a and listed in Table 2. Electrolyte solution for the solar cells (as well as for ensuing studies in this article) was comprised of $0.2 \mathrm{M} \mathrm{Cu}^{\mathrm{I}}$ and $0.04 \mathrm{M} \mathrm{Cu}^{\mathrm{II}}$ species of the respective complex. The reader is referred to Figures S6-S9 for measurement statistics, solar cell characterization at lower light intensity and studies concerning electrolyte compositions.

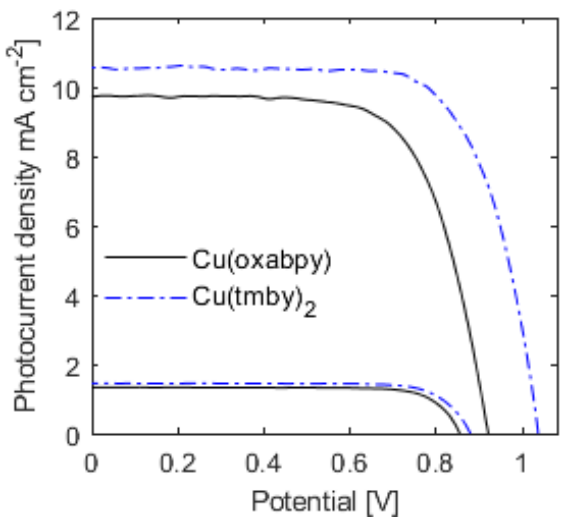

(a)

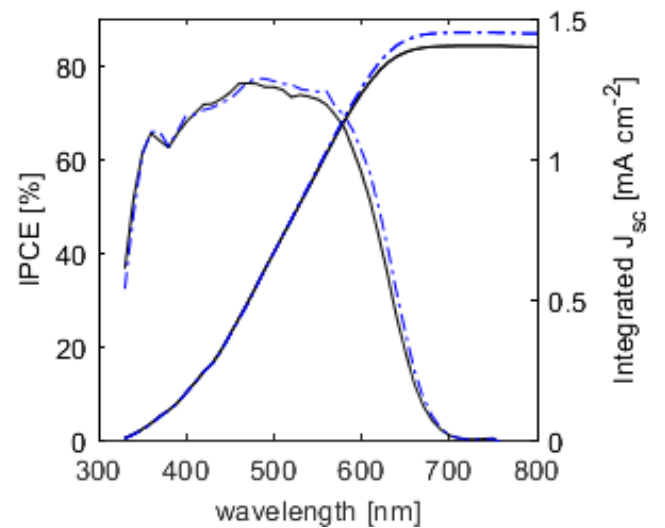

(b)

Figure 5. Photovoltaic performance. (a) Current density vs. applied potential under standard AM 1.5G illumination and 10\% light intensity; (b) Incident Photon-to-Current Conversion Efficiency (IPCE) for Y123-sensitized DSCs (recorded at $10 \mathrm{~mW} / \mathrm{cm}^{2}$ illumination). 
Table 2. $J-V$ characteristics for $\mathrm{Y} 123$-sensitized solar cells with $\mathrm{Cu}(\mathrm{tmby})_{2}$ and $\mathrm{Cu}(\mathrm{oxabpy})$ electrolyte under full AM 1.5G and under 10\% light intensity. For detailed characterization, the reader is referred to Figures S6-S9 in the Supporting Information.

\begin{tabular}{ccccc}
\hline Electrolyte & $\boldsymbol{V}_{\boldsymbol{o c}}(\mathbf{m V})$ & $J_{\mathbf{s c}}\left(\mathbf{m A} \cdot \mathbf{c m}^{-\mathbf{2}}\right)$ & Fill Factor & PCE (\%) \\
\hline $\mathrm{Cu}(\mathrm{tmby})_{2}$ & 1040 & 10.5 & 0.71 & 7.8 \\
$10 \%$ light & 875 & 1.44 & 0.78 & 10.0 \\
$\mathrm{Cu}(\mathrm{oxabpy})$ & 920 & 9.75 & 0.69 & 6.2 \\
$10 \%$ light & 855 & 1.32 & 0.79 & 8.9 \\
\hline
\end{tabular}

The open-circuit voltage $\left(V_{\mathrm{oc}}\right)$ of a dye-sensitized solar cell is given by the difference in energy between the Fermi level $\left(E_{\mathrm{F}}\right)$ in the mesoporous $\mathrm{TiO}_{2}$ and the effective redox potential of the electrolyte [11]. Solar cells with the $\mathrm{Cu}(\mathrm{tmby})_{2}$ redox couple show a photovoltage of $1040 \mathrm{mV}$, while those with $\mathrm{Cu}$ (oxabpy) exhibit a maximum photovoltage of $920 \mathrm{mV}$. Intriguingly, the $\mathrm{Cu}$ (oxabpy) redox couple ( $0.66 \mathrm{~V}$ vs. NHE) shows a $210 \mathrm{mV}$ lower formal redox potential compared to $\mathrm{Cu}$ (tmby $)_{2}(0.87 \mathrm{~V}$ vs. NHE) [20], while solar cells generate a photovoltage which is only $120 \mathrm{mV}$ lower. Slow recombination kinetics of excited electrons with $\mathrm{Cu}^{\mathrm{II}}$ (oxabpy) lead to a higher Fermi level in the $\mathrm{TiO}_{2}$ and thus to a high photovoltage. This effect will be further discussed in the lifetime measurements in Figure 6.

A slightly lower photocurrent of $9.75 \mathrm{~mA} \cdot \mathrm{cm}^{-2}$ is measured for the $\mathrm{Cu}$ (oxabpy) cells with respect to $10.5 \mathrm{~mA} \cdot \mathrm{cm}^{-2}$ for the $\mathrm{Cu}$ (tmby) $)_{2}$ system. At $10 \%$ light intensity, similar photocurrents are recorded with both electrolytes. Figure $5 b$ shows IPCE spectra for abovementioned Y123-sensitized solar cells recorded at $10 \%$ illumination intensity. IPCE spectra of DSCs with $\mathrm{Cu}(\mathrm{tmby})_{2}$ and $\mathrm{Cu}$ (oxabpy) electrolytes match well across the entire spectral range, yielding a similar integrated photocurrent for both electrolytes. Therefore, the lower photocurrent at full illumination for $\mathrm{Cu}$ (oxabpy) cells has to be attributed to mass transport deficiencies through the porous $\mathrm{TiO}_{2}$ network that originate from the high viscosity of the $\mathrm{Cu}$ (oxabpy) redox electrolyte. Investigations at 10\% light intensity (Figures S8 and S9) highlight that photocurrents with the $\mathrm{Cu}$ (oxabpy) redox couple can be enhanced up to $1.58 \mathrm{~mA} / \mathrm{cm}^{2}$, beyond the $1.45 \mathrm{~mA} / \mathrm{cm}^{2}$ obtained for $\mathrm{Cu}(\text { tmby) })_{2}$, upon further addition of $\mathrm{Cu}^{\mathrm{II}}$ (oxabpy) up to a 1:1 mixture of $\mathrm{Cu}^{\mathrm{I} / \mathrm{II}}$. This indicates that the presence of the $\mathrm{Cu}^{\mathrm{II}}$ species facilitates charge transport in the $\mathrm{Cu}$ (oxabpy) redox electrolyte. The increased presence of recombination sites in $\mathrm{Cu}^{\mathrm{II}}$ (oxabpy), however, leads to a decrease in photovoltage.

\subsection{Electron Lifetime Measurements}

Recombination kinetics between excited electrons in the $\mathrm{TiO}_{2}$ and the redox electrolyte were further investigated with electron lifetime measurements (Figure 6).

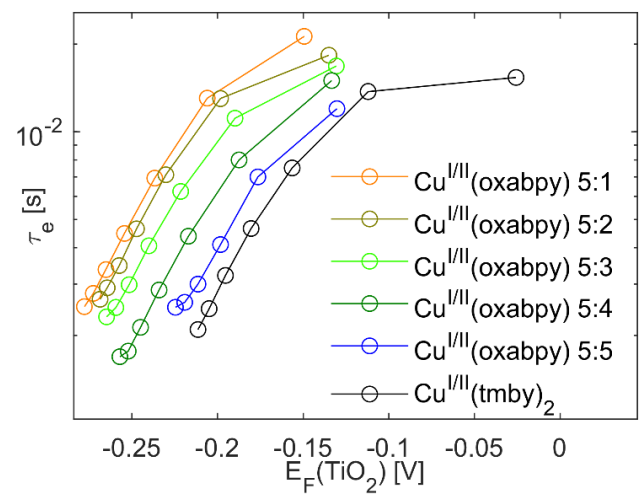

Figure 6. Electron lifetimes in $\mathrm{Y}_{123}$-sensitized $\mathrm{TiO}_{2}$ in $\mathrm{Cu}$ (tmby) $)_{2}$ (black) and $\mathrm{Cu}($ oxabpy) electrolyte. The color code indicates the ratio of $\mathrm{Cu}^{\mathrm{II}}$ in the $\mathrm{Cu}$ (oxabpy) electrolyte (orange = standard electrolyte $0.2 \mathrm{M} \mathrm{Cu}^{\mathrm{I}}, 0.04 \mathrm{M} \mathrm{Cu}^{\mathrm{II}}$; blue = 1:1 mixture). 
To demonstrate the influence of the $\mathrm{Cu}^{\mathrm{II}}$ content in the electrolyte on recombination kinetics, measurements are presented for electrolyte compositions from the standard 5:1 electrolyte (orange) stepwise to a 1:1 mixture of $\mathrm{Cu}^{\mathrm{I} / \mathrm{II}}$ (blue). $\mathrm{Cu}^{\mathrm{I}}$ concentration was kept constant in all compositions, the respective entry indicates the relative concentrations of $\mathrm{Cu}^{\mathrm{I}}$ and $\mathrm{Cu}{ }^{\mathrm{II}}$. The observation of a Fermi level shifts up to $70 \mathrm{mV}$ for the $\mathrm{Cu}$ (oxabpy) standard electrolyte compared to the $\mathrm{Cu}$ (tmby) ${ }_{2}$ reference supports the hypothesis of slow recombination kinetics for the $\mathrm{Cu}$ (oxabpy) redox couple. The shift in the Fermi level follows a consistent trend towards lower potentials upon increase of $\mathrm{Cu}^{\mathrm{II}}$ concentration in the electrolyte, as a larger number of recombination sites becomes available for excited electrons.

A number of processes are to be taken into account for recombination in DSCs [11]. Ultimately, electron lifetimes in the $\mathrm{Cu}$ (oxabpy) electrolyte (foremost for electrolytes with little $\mathrm{Cu}^{\mathrm{II}}$ ) exceed electron lifetimes for solar cells with the $\mathrm{Cu}(\mathrm{tmby})_{2}$ redox couple. In agreement with aforementioned observations, lifetimes of excited electrons in electrolytes with higher $\mathrm{Cu}^{\mathrm{II}}$ concentrations decrease due to additional recombination sites in the electrolyte. Therefore, an increased $\mathrm{Cu}^{\mathrm{II}}$ concentration leads, while it does facilitate charge transport (see Figure S10), to a lower open-circuit voltage.

\subsection{Dye Regeneration}

Photoinduced absorption spectroscopy (PIA) was employed to assess dye regeneration by the $\mathrm{Cu}$ (oxabpy) redox system. Figure 7a shows PIA spectra of Y123-sensitized photoanodes in inert and in $\mathrm{Cu}$ (oxabpy) electrolyte.

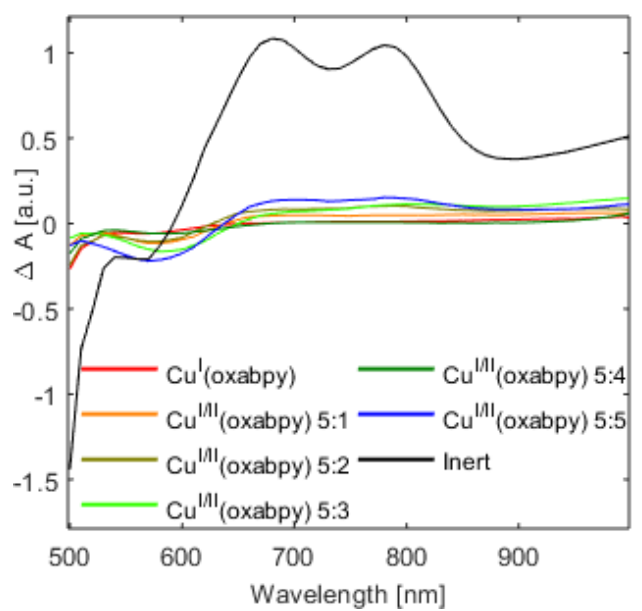

(a)

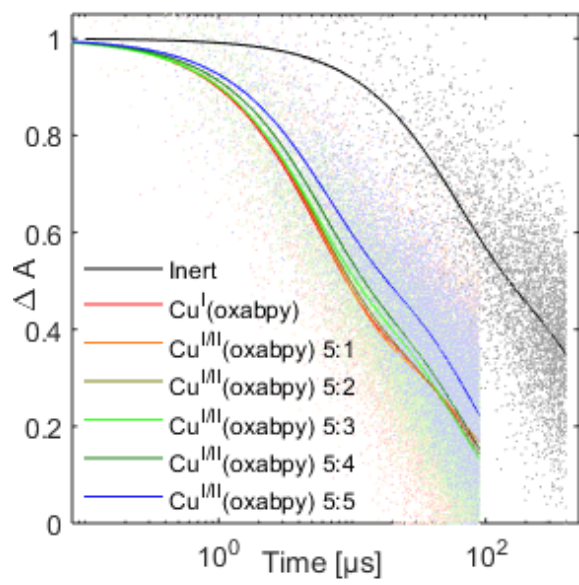

(b)

Figure 7. (a) Photoinduced absorption and (b) transient absorption spectra of Y123-sensitized photoanodes in inert (black) as well as $\mathrm{Cu}$ (oxabpy) electrolyte. The color code indicates the ratio of $\mathrm{Cu}^{\mathrm{II}}$ in the $\mathrm{Cu}$ (oxabpy) electrolyte (orange = standard electrolyte $0.2 \mathrm{M} \mathrm{Cu}^{\mathrm{I}}, 0.04 \mathrm{M} \mathrm{Cu}^{\mathrm{II}}$; blue = 1:1 mixture).

Scans were performed with a constant $\mathrm{Cu}^{\mathrm{I}}$ concentration of $0.2 \mathrm{M}$ in the electrolyte and increasing $\mathrm{Cu}^{\mathrm{II}}$ content according to the color code up to a 1:1 mixture (blue). In the case of inert electrolyte $(0.1 \mathrm{M}$ LiTFSI, 0.6 M tBP), the Y123-dye shows the characteristic Stark-shifted ground state bleach (500-600 nm) and the absorption of the oxidized dye $(680 \mathrm{~nm}, 800 \mathrm{~nm}$ ) [39]. For all constitutions of the $\mathrm{Cu}$ (oxabpy) electrolyte, the absorption of the dye in the oxidized state is largely suppressed. Therefore, it can be deduced that electrons are rapidly transferred from the redox electrolyte to the oxidized dye molecules. A bleach around 550-600 nm persists and can be attributed to local electric fields. Minor remaining absorption at near-infrared wavelengths are associated with electrons in the $\mathrm{TiO}_{2}$ [40]. Quenching of the oxidized dye decreases with increasing $\mathrm{Cu}^{\mathrm{II}}$ content in the electrolyte due to a reduced presence of the $\mathrm{Cu}^{\mathrm{I}}$ species in the immediate proximity of the oxidized dye. This effect was further studied with transient absorption spectroscopy (TAS, Figure 7b). Results are summarized in Table 3. 
Table 3. Regeneration times and efficiencies for Y123-sensitized photoanodes in inert and $\mathrm{Cu}$ (oxabpy) electrolyte, by addition of $\mathrm{Cu}^{\mathrm{II}}$ into the electrolyte.

\begin{tabular}{ccc}
\hline & $\tau_{\mathbf{1 / 2}}(\mu \mathbf{s})$ & $\boldsymbol{\varphi}_{\text {reg }}(\mathbf{\%})$ \\
\hline Inert & 104 & - \\
$\mathrm{Cu}$ (oxabpy) & 6.19 & 94.0 \\
$\mathrm{Cu}^{\mathrm{I} / \mathrm{II}}$ (oxabpy) 5:1 & 6.33 & 93.9 \\
$\mathrm{Cu}^{\mathrm{I} / \mathrm{II}}$ (oxabpy) 5:2 & 6.70 & 93.5 \\
$\mathrm{Cu}^{\mathrm{I} / \mathrm{II}}$ (oxabpy) 5:3 & 7.39 & 92.9 \\
$\mathrm{Cu}^{\mathrm{I} / \mathrm{II}}$ (oxabpy) 5:4 & 8.52 & 91.8 \\
$\mathrm{Cu}^{\mathrm{I} / \mathrm{II}}$ (oxabpy) 5:5 & 12.6 & 87.9 \\
\hline
\end{tabular}

In inert electrolyte (black), excited electrons in the $\mathrm{TiO}_{2}$ recombine with oxidized dye molecules with a half-time $\left(\tau_{1 / 2, \text { inert }}\right)$ of $104 \mu \mathrm{s}$. In the case of $\mathrm{Cu}$ (oxabpy) electrolyte, a significantly faster absorption decay $\left(\tau_{1 / 2, \text { reg }}\right)$ is observed for all compositions. Correspondingly, dye regeneration efficiency $\phi_{\text {reg }}$ can be calculated.

$$
\phi_{\text {reg }}=1-\frac{t_{1 / 2, \text { reg }}}{t_{1 / 2, \text { inert }}}
$$

The fastest regeneration of $6.19 \mu$ s is observed for the electrolyte with the $\mathrm{Cu}^{\mathrm{I}}$ species only, corresponding to a regeneration efficiency above $94 \%$. A coherent decrease in dye regeneration is subsequently observed upon addition of $\mathrm{Cu}^{\mathrm{II}}$ to the electrolyte as it hinders $\mathrm{Cu}^{\mathrm{I}}$ species from transferring charges to the dye molecules. The high regeneration efficiencies of the Y123 dye by the $\mathrm{Cu}$ (oxabpy) redox system prove efficient charge compensation in DSCs.

\subsection{Charge Transport in the Cu(oxabpy) Redox Electrolyte}

The charge transport in the $\mathrm{Cu}$ (oxabpy) electrolyte was investigated with symmetrical cells with poly(3,4-ethylenedioxythiophene) (PEDOT) contacts on either electrode. Figure 8a shows cyclic voltammograms of these symmetrical cells with the $\mathrm{Cu}(\mathrm{tmby})_{2}$ and $\mathrm{Cu}$ (oxabpy) redox couples. Results of these investigations are summarized in Table 4.

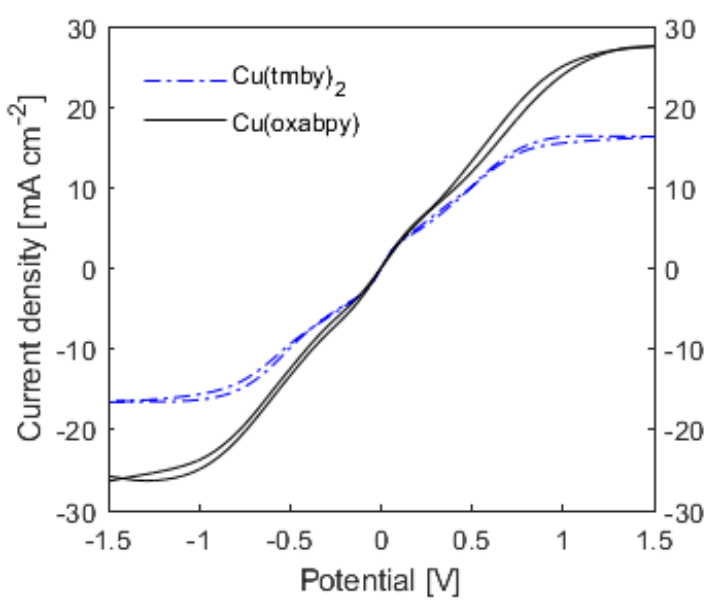

(a)

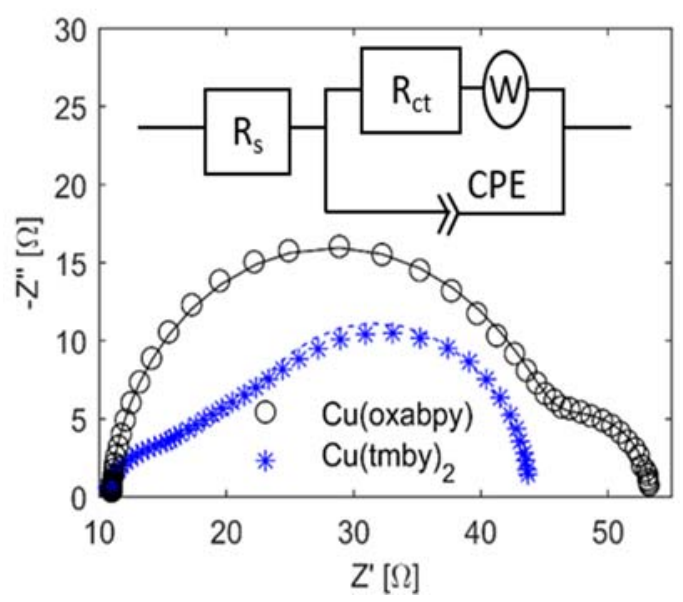

(b)

Figure 8. Electrochemical characterization of symmetrical PEDOT-PEDOT cells with $\mathrm{Cu}(\mathrm{tmby})_{2}$ and $\mathrm{Cu}$ (oxabpy) electrolyte. (a) Cyclic voltammetry (scan speed $25 \mathrm{mV} / \mathrm{s}$ ); (b) Electrochemical impedance spectra recorded at zero-potential; the circles indicate experimentally collected data points, dashed lines represent fits to the alternative circuit model (inset). Figures S10 and S11 and Table S2 include investigations for varying $\mathrm{Cu}^{\mathrm{I} / \mathrm{II}}$ (oxabpy) electrolyte composition. 
The shape of the cyclic voltammograms at low potentials follows that of a characteristic ohmic resistance. From potentials around $1 \mathrm{~V}$, however, mass transport deficiencies impede the charge transport. In this diffusion-limited region at high potentials, cells with the $\mathrm{Cu}$ (oxabpy) redox electrolyte exhibit a 1.7 times higher current at similar potential compared to the $\mathrm{Cu}(\mathrm{tmby})_{2}$ reference cells. The limiting current can be directly associated with the diffusion of the copper complexes in the electrolyte,

$$
J_{L}=\frac{2 n F c D}{\delta}
$$

where $n$ is the number of exchanged electrons ( $n=1$ for common copper-based redox systems), $F$ represents the Faraday constant, $c$ and $D$ are the concentration and the diffusion coefficient of the limiting species (i.e., the minority species, in these cases the $\mathrm{Cu}^{\mathrm{II}}$ ), and $\delta$ is the spacing between the electrodes.

Table 4. Electrochemical characterization of symmetrical PEDOT-PEDOT cells. The first two rows list current density $J_{L}$ and diffusion coefficient $D$ from the cyclovoltammograms. The equivalent circuit parameters for the electrochemical impedance spectra are: serial resistance $R_{S}$, charge transfer resistance $R_{C T}$, frequency-independent parameters $Q$ and $\beta$ for the constant phase element and resistance $R_{W}$, as well as time constant $T_{W}$, for the Warburg diffusion model. Diffusion coefficients from the electrochemical impedance spectra are shown in the last row. The diffusion coefficients were calculated from Equations (2) and (5), respectively. Previously reported values in parenthesis.

\begin{tabular}{ccc}
\hline & Cu(tmby $)_{2}$ & Cu(oxabpy) \\
\hline$J_{L}\left(\mathrm{~mA} \mathrm{~cm}^{-2}\right)$ & 16.6 & 27.5 \\
$R_{S}(\Omega)$ & $8.6(10 ; 12)[41,42]$ & 14.3 \\
$R_{C T}(\Omega)$ & 10.5 & 10.8 \\
$\mathrm{CPE}: Q\left(10^{-3} \Omega^{-1} \mathrm{~s}^{-\beta}\right)$ & 6.92 & 33.4 \\
$\mathrm{CPE}: \beta$ & 0.337 & 0.124 \\
$\mathrm{~W}: R_{w}(\Omega)$ & 0.847 & 0.967 \\
$\mathrm{~W}: T_{w}(\mathrm{~s})$ & 26.5 & 9.09 \\
$\left.\mathrm{~s}^{-1}\right)$ for Cu & 0.285 \\
$D\left(10^{-6} \mathrm{~cm}^{2} \mathrm{~s}^{-1}\right)$ for $\mathrm{Cu}{ }^{\mathrm{II}}$ from $R_{w}$ & $22.4(22 ; 26)[20,41]$ & 63.7 \\
\hline
\end{tabular}

The diffusion coefficients for $\mathrm{Cu}^{\mathrm{II}}(\mathrm{tmby})_{2}$ and $\mathrm{Cu}^{\mathrm{II}}$ (oxabpy) obtained from the cyclic voltammograms are calculated in Table 4 . The diffusion coefficient for $\mathrm{Cu}(\mathrm{tmby})_{2}$ is estimated around $8.6 \mathrm{~cm}^{2} / \mathrm{s}$, slightly lower but within reasonable agreement with previously reported values from similar experimental setups [41,42]. The higher limiting current for the Cu(oxabpy) system yields a correspondingly 1.7 times higher diffusion coefficient of $14.3 \mathrm{~cm}^{2} / \mathrm{s}$. A faster transport in the $\mathrm{Cu}$ (oxabpy) gel-like electrolyte appears intriguing when related to the fact that its viscosity was estimated more than 2.5 times higher than that of $\mathrm{Cu}(\mathrm{tmby})_{2}$. The enhanced charge transport properties are hence to be attributed to superposition of diffusion with an additional transport mechanism such as charge hopping. The square-planar coordination geometry of $\mathrm{Cu}$ (oxabpy) complexes appears to enable direct electronic interactions between the complexes, leading to charge-hopping transitions along $\mathrm{Cu}$ (oxabpy) complexes and thus a more effective charge transport in the electrolyte. Such charge transport based on intermolecular transfers had previously been successfully demonstrated in copper complexes as solid hole transport materials [25,43].

The advanced charge transport in the $\mathrm{Cu}$ (oxabpy) redox electrolyte was also observed in electrochemical impedance spectroscopy on symmetrical PEDOT-PEDOT cells (Figure 8b). Experimental results (circles/stars) were fitted to the alternative circuit shown in the inlet.

A constant phase element (CPE) was proposed for the impedance of the electrochemical double layer at the PEDOT/electrolyte interface,

$$
Z_{C P E}=\frac{1}{Q(i \omega)^{\beta}}
$$


where $\omega$ represents the frequency, and $Q$ and $\beta$ represent the parameters of the CPE. The constraint of $0 \leq \beta \leq 1$ was applied for the fitting of experimental data. A short-circuit Warburg model was applied for the diffusion impedance parallel to the CPE,

$$
Z_{w}=\frac{R_{w}}{\sqrt{T_{w} i \omega}} \tanh \left(\sqrt{T_{w} i \omega}\right)
$$

where $\omega$ is the frequency, $R_{W}$ the diffusion resistance and $T_{W}$ the diffusion time constant, which are defined as

$$
R_{w}=\frac{R T \delta}{z^{2} F^{2} A c D} ; T_{w}=\frac{\delta^{2}}{D}
$$

with the absolute temperature $T$, the gas constant $R$, cell spacing $\delta$, number of charges $z$, Faraday constant $F$, area $A$ and concentration $c$, as well as diffusion coefficient $D$ for the transport-limiting species (here the $\mathrm{Cu}^{\mathrm{II}}$ ) [44]. Resistances were inserted at the beginning of the circuit as well as before the diffusion element.

$$
Z=R_{S}+\frac{Z_{C P E}\left(R_{C T}+Z_{w}\right)}{Z_{C P E}+R_{C T}+Z_{w}}
$$

Fitted parameters are summarized in Table 4. Electrochemical impedance spectra of symmetrical PEDOT-PEDOT cells generally exhibit two semicircles, originating from the charge transfer resistance at the electrolyte/PEDOT interface and from the diffusion impedance. The charge transfer resistance dominates the impedance response for the $\mathrm{Cu}$ (oxabpy) system while this contribution becomes less significant for the $\mathrm{Cu}\left(\mathrm{tmby}_{2}\right.$ electrolyte, where a more distinct diffusion impedance arises. The high charge transfer resistance in the case of the $\mathrm{Cu}$ (oxabpy) redox system corresponds to a slower charge transfer rate at the electrolyte/PEDOT interface. This can be directly related to the lower fill factor in the solar cell devices.

Diffusion coefficients in the redox electrolytes were deduced from the fitted diffusion resistances $R_{W}$ according to Equation (5). The estimated diffusion coefficient for the diffusion-limiting $\mathrm{Cu}^{\mathrm{II}}\left(\mathrm{tmby}_{2}\right.$ of $22.4 \times 10^{-6} \mathrm{~cm}^{2} / \mathrm{s}$ is found in excellent agreement with previously reported values and supports the proposed equivalent circuit model [20,41]. A similar circuit model was applied to fit the impedance spectrum of $\mathrm{Cu}$ (oxabpy). The agreement between experimental data and the equivalent circuit fit indicates that diffusive mass transport is the determining charge transport mechanism. The obtained diffusion coefficient for $\mathrm{Cu}^{\mathrm{II}}$ (oxabpy) of $63.7 \times 10^{-6} \mathrm{~cm}^{2} / \mathrm{s}$ exceeds the diffusion coefficient of $\mathrm{Cu}^{\mathrm{II}}(\mathrm{tmby})_{2}$ by a factor of 2.8. With respect to the higher viscosity of the $\mathrm{Cu}(\mathrm{oxabpy})$ electrolyte, this result supports the above-proposed superposition of diffusive mass transport with a hole-hopping mechanism.

Both cyclic voltammetry and electrochemical impedance spectra indicate a significantly enhanced charge transport in the $\mathrm{Cu}$ (oxabpy) electrolyte with respect to $\mathrm{Cu}(\mathrm{tmby})_{2}$. Nonetheless, higher photocurrents were, at full illumination, measured with the $\mathrm{Cu}(\mathrm{tmby})_{2}$ redox electrolyte. This indicates that the mesoporous $\mathrm{TiO}_{2}$ hinders charge transport in the $\mathrm{Cu}$ (oxabpy) system.

\section{Materials and Methods}

\subsection{Materials}

Unless otherwise noted, materials were purchased from Sigma-Aldrich (Stockholm, Sweden) or TCI Chemicals (Zwijndrecht, Belgium) and used without further purification. Bis- $\left(4,4^{\prime}, 6,6^{\prime}\right.$-tetramethyl2,2'-bipyridine)copper ${ }^{\mathrm{I} / \mathrm{II}}$ bis(trifluoromethanesulfonyl)imide, $\left(\mathrm{Cu}^{\mathrm{I} / \mathrm{II}}\left(\mathrm{tmby}_{2}\right)\right.$, was received from Dyenamo AB (Stockholm, Sweden). 
3.2. Synthesis of (6,6'-bis(4-(S)-isopropyl-2-oxazolinyl)-2,2'-bipyridine)Copper(II)

bis (bis(trifluoromethanesulfonyl)imide) (Cu (oxabpy))

$\mathrm{Cu}^{\mathrm{II}}$ (oxabpy) was synthesized by reacting CuTFSI 2 (779.75 mg, $1.25 \mathrm{mmol}$ ) with 6,6'-bis(4-(S)isopropyl-2-oxazolinyl)-2,2'-bipyridine $\left(567 \mathrm{mg}, 1.5 \mathrm{mmol}\right.$ ) in acetonitrile at $70{ }^{\circ} \mathrm{C}$ for $12 \mathrm{~h}$. The development of a deep blue/green color indicated complexation. The complex was precipitated in water and filtered. The product was dissolved in acetonitrile and dried with sodium sulfate. The solvent was subsequently removed and the product dried under high vacuum for $48 \mathrm{~h}(63.8 \%)$. ESI-MS $\mathrm{m} / \mathrm{z}$ : $\mathrm{Cu}(\text { oxabpy })^{2+}$ calculated 220.567, found 220.600. FT-IR $\left(\mathrm{cm}^{-1}\right)$ : C-H stretch 2978, 2931, 2893; C-H bend 1454; $\mathrm{S}=\mathrm{O}$ stretch 1381; $\mathrm{C}=\mathrm{N}$ (aromatic) stretch 1327; $\mathrm{C}-\mathrm{O}$ (ether) stretch 1157; $\mathrm{CH}_{3}$ rock 1049; $\mathrm{C}=\mathrm{C}$ bend 887; Elemental analysis (calculated/found (\%)): C 39.92/41.51, H 3.63/3.87, Cu 8.80/8.25, N 9.70/9.94, S 8.88/9.71.

\subsection{Synthesis of (6,6'-bis(4-(S)-isopropyl-2-oxazolinyl)-2,2'-bipyridine)Copper(I) bis(trifluoromethanesulfonyl)imide (Cu (oxabpy))}

$\mathrm{Cu}^{\mathrm{I}}$ (oxabpy) was obtained by reducing the aforementioned $\mathrm{Cu}^{\mathrm{II}}$ (oxabpy) $(450 \mathrm{mg}, 0.448 \mathrm{mmol}$ ) with L-ascorbic acid ( $236 \mathrm{mg}, 1.344 \mathrm{mmol})$ in acetonitrile for $2 \mathrm{~h}$. A brown color indicating the formation of $\mathrm{Cu}^{\mathrm{I}}$ (oxabpy) was observed after several minutes. Precipitation in water was followed by filtration, dissolution in acetonitrile, and drying with sodium sulfate. After solvent removal, the complex was dried under high vacuum for $48 \mathrm{~h}(81.2 \%)$. ESI-MS $m / z$ : $\mathrm{Cu}(\text { oxabpy })^{+}$calculated 441.135 , found 441.059. ${ }^{1} \mathrm{H}$ NMR (400 MHz, Acetonitrile- $\left.d_{3}\right) \delta 8.36(\mathrm{t}, J=15.2 \mathrm{~Hz}, 2 \mathrm{H}), 8.36(\mathrm{~d}, J=15.0 \mathrm{~Hz}, 2 \mathrm{H}), 8.04$ $(\mathrm{dd}, J=7.5,1.3 \mathrm{~Hz}, 2 \mathrm{H}), 4.45(\mathrm{t}, J=9.6 \mathrm{~Hz}, 2 \mathrm{H}), 4.34(\mathrm{t}, J=9.1 \mathrm{~Hz}, 2 \mathrm{H}), 2.81(\mathrm{td}, J=9.4,5.9 \mathrm{~Hz}, 2 \mathrm{H})$, 1.47 (oct, $J=6.9 \mathrm{~Hz}, 2 \mathrm{H}), 0.55(\mathrm{t}, J=6.3 \mathrm{~Hz}, 12 \mathrm{H})$. FT-IR $\left(\mathrm{cm}^{-1}\right)$ : C-H stretch 2978, 2931, 2885; C-H bend 1454; $\mathrm{S}=\mathrm{O}$ stretch 1381; $\mathrm{C}=\mathrm{N}$ (aromatic) stretch 1296; $\mathrm{C}-\mathrm{O}$ (ether) stretch 1095; $\mathrm{CH}_{3}$ rock 1057; $\mathrm{C}=\mathrm{C}$ bend 887; Elemental analysis (calculated/found (\%)): C 31.16/35.27, H 2.61/3.67, Cu 6.34/5.42, N 8.38/9.03, S 12.79/13.55.

\subsection{UV/VIS Spectroscopy}

UV/VIS spectra were measured using a HR-2000 spectrophotometer (Ocean Optics, Largo, FL, USA) with baseline correction from acetonitrile solutions of the complexes.

\subsection{Viscosity Measurements}

Viscosities were studied with a capillary and ViscoClock (Schott, Mainz, Germany). The test solutions for both $\mathrm{Cu}^{\mathrm{I} / \mathrm{II}}\left(\mathrm{tmby}_{2}\right.$ as well as $\mathrm{Cu}^{\mathrm{I} / \mathrm{II}}$ (oxabpy) were prepared with $10 \mathrm{mg} / \mathrm{mL}$ in chloroform. The complexes were mixed in a 5:1 ratio such as in the electrolyte ( $\mathrm{Cu}(\text { tmby })_{2}: 7.85 \mathrm{mg} \mathrm{Cu}^{\mathrm{I}}, 2.14 \mathrm{mg} \mathrm{Cu}{ }^{\mathrm{II}}$; $\mathrm{Cu}$ (oxabpy): $7.82 \mathrm{mg} \mathrm{Cu}^{\mathrm{I}}, 2.17 \mathrm{mg} \mathrm{Cu}^{\mathrm{II}}$ ). LiTFSI as well as tBP were excluded from the measurements.

\subsection{Raman Spectroscopy}

Raman spectra were collected using an InVia spectrometer (Renishaw, New Mills, UK) in confocal mode with a $50 \times$ objective, a frequency doubled Nd:YAG laser operating at $532 \mathrm{~nm}$, and a Rayleigh line filter cutting $80 \mathrm{~cm}^{-1}$ into the Stokes part of the spectra. A 2400 lines $/ \mathrm{mm}$ grating was used and the $520.5 \mathrm{~cm}^{-1}$ line from $\mathrm{Si}$ was used as a calibration giving a resolution of $1 \mathrm{~cm}^{-1}$. The Raman spectra were recorded at different spots to confirm the homogeneity of the material. Similar results were obtained upon repetition of the measurements with varying laser intensities.

\subsection{Solar Cell Fabrication}

Solar cell fabrication followed procedures previously reported from our laboratory [18]. Solar cells were manufactured using TEC15 FTO glass (Pilkington, St. Helens, UK). After several glass cleaning steps (RBS solution, water, ethanol, UV-Ozone (30 min each)), a dense $\mathrm{TiO}_{2}$ layer was deposited via spray pyrolysis at $450{ }^{\circ} \mathrm{C}$ from a $0.2 \mathrm{M}$ titanium tetraisopropoxide, $2 \mathrm{M}$ acetylacetone 
solution in isopropanol [45]. Subsequently, $0.25 \mathrm{~cm}^{2} \mathrm{TiO}_{2}$ photoanodes were screen-printed from Dyesol/GreatCellSolar (Queanbeyan, Australia) DSL 30 NRD-T collodidal $\mathrm{TiO}_{2}$ paste diluted 7:3 with a saturated solution of cellulose in terpineol $(4 \mu \mathrm{m})$. After drying at $120^{\circ} \mathrm{C}$ for $5 \mathrm{~min}$, a scattering layer (Dyesol/GreatCellSolar WER2-0) was screen-printed on top of the mesoporous film $(4 \mu \mathrm{m})$, followed by a $30 \mathrm{~min}$ sintering step at $500^{\circ} \mathrm{C}$. After cooling, substrates were immersed in a $40 \mathrm{mM}$ $\mathrm{TiCl}_{4}$ aqueous solution for $30 \mathrm{~min}$ at $70{ }^{\circ} \mathrm{C}$ and then sintered again at $500{ }^{\circ} \mathrm{C}$ for $30 \mathrm{~min}$.

Dye solution was prepared with $0.1 \mathrm{mM}$ Y123 (Dyenamo, Stockholm, Sweden) and $0.2 \mathrm{mM}$ chenodeoxycholic acid in an acetonitrile 1:1 tert-butanol mixture. $\mathrm{TiO}_{2}$ substrates were immersed in dye solution for $16 \mathrm{~h}$ after the aforementioned heating step.

PEDOT counter electrodes were manufactured by electro-polymerization of (3,4-ethylene dioxythiophene) from a $0.01 \mathrm{mM}$ aqueous solution with $0.1 \mathrm{M}$ sodium dodecyl sulfate as previously studied in our group [46]. Redox electrolyte solutions were, unless otherwise noted, prepared in acetonitrile with $0.2 \mathrm{M} \mathrm{Cu}$ (oxabpy)TFSI and $\mathrm{Cu}$ (oxabpy)TFSI $\mathrm{T}_{2}$ concentrations between 0 and $0.2 \mathrm{M}$. Reference cells were assembled with $0.2 \mathrm{M} \mathrm{Cu}$ (tmby)TFSI and $0.04 \mathrm{M} \mathrm{Cu}$ (tmby)TFSI ${ }_{2}$ electrolyte [20]. All electrolytes were prepared with additions of $0.1 \mathrm{M}$ lithium bis(trifluoromethanesulfonyl)imide and $0.6 \mathrm{M}$ 4-tert-butylpyridine.

Cells were assembled with a $25 \mu \mathrm{m}$ Surlyn frame. Electrolyte solution was vacuum-injected through a pre-drilled hole in the counter electrode. After injection, the cells were sealed with a thermoplastic Surlyn cover and a glass coverslip.

\subsection{Solar Cell Characterization}

Current-Voltage measurements were carried out under AM 1.5G illumination using a 91160 solar simulator (Newport, Irvine, CA, USA). A 2400 voltage source (Keithley, Cleveland, OH, USA) was used to assess solar cell performance. After calibration with a certified silicon reference cell (Frauenhofer ISE, München, Germany), a mask was employed to confine active solar cell area to $0.16 \mathrm{~cm}^{2}$. Neutral density filters were placed between the light source and each cell to perform low light intensity measurements.

\subsection{Incident Photon-to-Current Conversion Efficiency (IPCE)}

IPCE spectra were recorded with an ASB-XE-175 xenon light source $\left(10 \mathrm{~mW} \cdot \mathrm{cm}^{-2}\right)$ (Spectral Products, Putnam, CT, USA) and a CM110 monochromator (Spectral Products, Putnam, CT, USA). The photocurrent was measured with a U6 digital acquisition board (LabJack, Lakewood, CO, USA). The setup was calibrated with a certified silicon reference cell (Frauenhofer ISE, München, Germany). Photocurrent was integrated based on sunlight spectral distribution [47].

\subsection{Electrochemistry}

Electrochemical characterization was carried out with an XR potentiostat (Ivium, Eindhoven, The Netherlands). Cyclic voltammetry was recorded using a three-electrode setup employing a $2 \mathrm{~mm}$ disk gold electrode and a porous graphite rod as working and counter electrode, respectively. Potentials were measured against a $\mathrm{Ag} / \mathrm{AgCl}\left(1 \mathrm{M} \mathrm{KCl}, \mathrm{H}_{2} \mathrm{O}\right)$ reference electrode. Voltammograms were recorded from a $5 \mathrm{mM}$ acetonitrile solution of $\mathrm{Cu}^{\mathrm{I}}$ (oxabpy) with $0.1 \mathrm{M}$ tetrabutylammonium hexafluorophosphate supporting electrolyte at a scan speed of $20 \mathrm{mV} / \mathrm{s}$. All potentials were subsequently calibrated using the ferrocene/ferrocenium redox couple, measured in the same conditions.

For assessment of the charge transport in the electrolyte, symmetrical PEDOT-PEDOT cells were assembled. Therefore, the abovementioned electrochemical polymerization of 3,4-ethylene dioxythiophene was employed to deposit contacts on both anode and cathode. The cells were assembled, injected and sealed as described for the photovoltaic cells above.

Limiting currents in the electrolyte systems were determined through cyclic voltammetry of these symmetrical PEDOT-PEDOT cells. Voltammograms were recorded at a scan speed of $25 \mathrm{mV} / \mathrm{s}$. 
Electrochemical impedance spectra were recorded at zero-potential on symmetrical PEDOT-PEDOT cells. The voltage was modulated by $10 \mathrm{mV}$ with frequencies ranging from $100 \mathrm{kHz}$ to $0.1 \mathrm{~Hz}$. Devices were kept screened from any light source during measurements.

\subsection{Electron Lifetime Measurements}

Electron lifetimes were investigated with a $1 \mathrm{~W}$ white LED (Luxeon Star, Lethbridge, Canada). Kinetics in the solar cell were probed by applying square-wave modulations to the light intensity. Solar cell response was tracked by a digital acquisition board (National Instruments, Austin, Texas) and fitted with first-order kinetic models.

\subsection{Photoinduced Absorption Spectroscopy (PIA)}

PIA spectra were recorded using square-wave-modulated blue light (1 W, $460 \mathrm{~nm})$ (Luxeon Star, Lethbridge, Canada), for excitation and white probe light (20 W tungsten-halogen) that was focused on a SP-150 monochromator (Acton Research Corp., Birmingham, AL, USA) with a UV-enhanced Si-photodiode. At sample location, pump and probe light intensities were estimated around $80 \mathrm{~W} / \mathrm{m}^{2}$ and $100 \mathrm{~W} / \mathrm{m}^{2}$, respectively. The sample response was assessed with a SR570 current amplifier and a SR830 lock-in amplifier (Stanford Research Systems, Reamwood, CA, USA).

\subsection{Transient Absorption Spectroscopy (TAS)}

TAS spectra were recorded using a frequency-tripled Q-switched Nd-YAG laser as pump and a xenon arc lamp (continuous wave) as probe light source. The laser system was set to $520 \mathrm{~nm}$ excitation wavelength with a S12 Quanta-Ray optical parametric oscillator (Spectra Physics, Santa Clara, CA, USA) to provide $1 \mathrm{~mJ}, 13 \mathrm{~ns}$ pulses at an operating frequency of $10 \mathrm{~Hz}$. The sample was positioned at an angle of $45^{\circ}$ between the light sources, yielding a $0.35 \mathrm{~cm}^{2}$ cross-sectional active area. The sample response was analyzed at $720 \mathrm{~nm}$ with an L920 detection unit (Edinburgh Instruments, Livingston, UK) containing a monochromator, an R928 photomultiplier and a TDS 3052B oscilloscope (Tektronix, Beaverton, OR, USA).

\section{Conclusions}

A new redox electrolyte based on $\mathrm{Cu}^{\mathrm{I} / \mathrm{II}}$ (oxabpy) complexes was successfully introduced in dye-sensitized solar cells. The improved charge transport in the gel-like electrolyte appears to originate from a charge hopping mechanism on top of diffusive transport. The $\mathrm{Cu}$ (oxabpy) electrolyte outperformed the previously reported $\mathrm{Cu}(\mathrm{tmby})_{2}$ redox system in charge transport tests by $70 \%$. Furthermore, the $\mathrm{Cu}$ (oxabpy) redox system shows slow recombination kinetics with electrons in the $\mathrm{TiO}_{2}$. Consequently, an exceptionally high photovoltage of $920 \mathrm{mV}$ (at $100 \mathrm{~mW} / \mathrm{cm}^{2} \mathrm{AM}$ $1.5 \mathrm{G}$ illumination) was achieved despite the moderate redox potential of $0.66 \mathrm{~V}$ vs. NHE. Rapid regeneration of the Y123 dye showed efficient charge transfer by the electrolyte. The tetradentate 6,6'-bis(4-(S)-isopropyl-2-oxazolinyl)-2,2'-bipyridine ligand reduces reorganization energies upon oxidation state change, making the $\mathrm{Cu}$ (oxabpy) electrolyte a premiere redox system for large-scale applications of DSCs. The gelation effects in the $\mathrm{Cu}$ (oxabpy) will be further studied in future work. Due to its charge transport characteristics, the $\mathrm{Cu}^{\mathrm{I} / \mathrm{II}}$ (oxabpy) redox couple furthermore promises to be suited as a solid-state hole-transport material.

Supplementary Materials: The following are available online at Supplementary materials can be found at http:/ / www.mdpi.com/2304-6740/6/2/53/s1, Figure S1: Cyclic Voltammetry of Cu(oxabpy), Figure S2: Viscosity study, Figure S3: DFT-estimated lowest energy structures with TFSI coordination, Figures S4 and S5: DFT-estimated frontier orbitals, Table S1: DFT-estimated optical transitions, Figures S6 and S7: Statistical assessment of photovoltaic performance, Figures S8 and S9: Statistical assessment of photovoltaic performance at low light intensity, Figures S10 and S11 and Table S2: Cyclic voltammetry and electrochemical impedance spectra on symmetrical PEDOT-PEDOT cells. 
Author Contributions: M.F. conceptualized and supervised the study; H.M. synthesized the copper complexes and carried out the material/device characterizations. T.E. measured and analyzed the Raman spectra. A.B.M.-G. And M.P. performed the DFT calculations. H.M. wrote the manuscript with contributions from T.E., A.B.M.-G., and M.P.; I.B. And G.B. revised the manuscript.

Funding: This work was supported by the Swedish Energy Agency (42037-1 and 43294-1), by the STandUP for Energy program and the Carl Trygger Stiftelse 17:158.

Acknowledgments: We acknowledge experimental assistance on viscosity from Janne Bohlin (Polymer chemistry, Uppsala) and Leif Häggman (Physical chemistry, Uppsala). We are truly grateful for inspiring discussions at the Uppsala Teknolog-och Naturvetarkår.

Conflicts of Interest: The authors declare no conflict of interest.

\section{References}

1. Hagfeldt, A.; Boschloo, G.; Sun, L.; Kloo, L.; Pettersson, H. Dye-Sensitized Solar Cells. Chem. Rev. 2010, 110, 6595-6663. [CrossRef] [PubMed]

2. Gerischer, H. The impact of semiconductors on the concepts of electrochemistry. Electrochim. Acta 1990, 35, 1677-1699. [CrossRef]

3. O'Regan, B.; Gratzel, M. A Low-Cost, High-Efficiency Solar-Cell Based on Dye-Sensitized Colloidal TiO 2 Films. Nature 1991, 353, 737-740. [CrossRef]

4. Asim, N.; Sopian, K.; Ahmadi, S.; Saeedfar, K.; Alghoul, M.A.; Saadatian, O.; Zaidi, S.H. A review on the role of materials science in solar cells. Renew. Sustain. Energy Rev. 2012, 16, 5834-5847. [CrossRef]

5. Gong, J.; Liang, J.; Sumathy, K. Review on dye-sensitized solar cells (DSSCs): Fundamental concepts and novel materials. Renew. Sustain. Energy Rev. 2012, 16, 5848-5860. [CrossRef]

6. Hagfeldt, A.; Grätzel, M. Molecular photovoltaics. Acc. Chem. Res. 2000, 33, 269-277. [CrossRef] [PubMed]

7. Kakiage, K.; Aoyama, Y.; Yano, T.; Oya, K.; Fujisawa, J.; Hanaya, M. Highly-efficient dye-sensitized solar cells with collaborative sensitization by silyl-anchor and carboxy-anchor dyes. Chem. Commun. 2015, 51, 15894-15897. [CrossRef] [PubMed]

8. Boschloo, G.; Hagfeldt, A.; Spectus, C.O.N. Characteristics of the Iodide/Triiodide Redox Mediator in Dye-Sensitized Solar Cells. Acc. Chem. Res. 2009, 42, 1819-1826. [CrossRef] [PubMed]

9. Privalov, T.; Boschloo, G.; Hagfeldt, A.; Svensson, P.H.; Kloo, L. A study of the interactions between $\mathrm{I}^{-} / \mathrm{I}_{3}{ }^{-}$redox mediators and organometallic sensitizing dyes in solar cells. J. Phys. Chem. C 2009, 113, 783-790. [CrossRef]

10. Nazeeruddin, M.K.; De Angelis, F.; Fantacci, S.; Selloni, A.; Viscardi, G.; Liska, P.; Ito, S.; Takeru, B.; Grätzel, M. Combined experimental and DFT-TDDFT computational study of photoelectrochemical cell ruthenium sensitizers. J. Am. Chem. Soc. 2005, 127, 16835-16847. [CrossRef] [PubMed]

11. Feldt, S.M.; Wang, G.; Boschloo, G.; Hagfeldt, A. Effects of Driving Forces for Recombination and Regeneration on the Photovoltaic Performance of Dye-Sensitized Solar Cells using Cobalt Polypyridine Redox Couples. J. Phys. Chem. C 2011, 115, 21500-21507. [CrossRef]

12. Feldt, S.M.; Gibson, E.A.; Gabrielsson, E.; Sun, L.; Boschloo, G.; Hagfeldt, A. Design of Organic Dyes and Cobalt Polypyridine Redox Mediators for High-Efficiency Dye-Sensitized Solar Cells. J. Am. Chem. Soc. 2010, 132, 16714-16724. [CrossRef] [PubMed]

13. Sapp, S.A.; Elliott, C.M.; Contado, C.; Caramori, S.; Bignozzi, C.A. Substituted Polypyridine Complexes of Cobalt(II/III) as Efficient Electron-Transfer Mediators in Dye-Sensitized Solar Cells. J. Am. Chem. Soc. 2002, 124, 11215-11222. [CrossRef] [PubMed]

14. Klahr, B.M.; Hamann, T.W. Performance enhancement and limitations of cobalt bipyridyl redox shuttles in dye-sensitized solar cells. J. Phys. Chem. C 2009, 113, 14040-14045. [CrossRef]

15. Nelson, J.J.; Amick, T.J.; Elliott, C.M. Mass Transport of Polypyridyl Cobalt Complexes in Dye-Sensitized Solar Cells with Mesoporous TiO Photoanodes Mass Transport of Polypyridyl Cobalt Complexes in Dye-Sensitized Solar Cells with Mesoporous $\mathrm{TiO}_{2}$ Photoanodes. J. Phys. Chem. C 2008, 112, 18255-18263. [CrossRef]

16. Cameron, P.J.; Peter, L.M.; Zakeeruddin, S.M.; Grätzel, M. Electrochemical studies of the $\mathrm{Co}(\mathrm{III}) / \mathrm{Co}(\mathrm{II})(\mathrm{dbbip}) 2$ redox couple as a mediator for dye-sensitized nanocrystalline solar cells. Coord. Chem. Rev. 2004, 248, 1447-1453. [CrossRef] 
17. Hattori, S.; Wada, Y.; Yanagida, S.; Fukuzumi, S. Blue copper model complexes with distorted tetragonal geometry acting as effective electron-transfer mediators in dye-sensitized solar cells. J. Am. Chem. Soc. 2005, 127, 9648-9654. [CrossRef] [PubMed]

18. Freitag, M.; Giordano, F.; Yang, W.; Pazoki, M.; Hao, Y.; Zietz, B.; Grätzel, M.; Hagfeldt, A.; Boschloo, G. Copper Phenanthroline as a Fast and High-Performance Redox Mediator for Dye-Sensitized Solar Cells. J. Phys. Chem. C 2016, 120, 9595-9603. [CrossRef]

19. Bai, Y.; Yu, Q.; Cai, N.; Wang, Y.; Zhang, M.; Wang, P. High-efficiency organic dye-sensitized mesoscopic solar cells with a copper redox shuttle. Chem. Commun. 2011, 47, 4376-4378. [CrossRef] [PubMed]

20. Saygili, Y.; Söderberg, M.; Pellet, N.; Giordano, F.; Cao, Y.; Munoz-García, A.B.; Zakeeruddin, S.M.; Vlachopoulos, N.; Pavone, M.; Boschloo, G.; et al. Copper Bipyridyl Redox Mediators for Dye-Sensitized Solar Cells with High Photovoltage. J. Am. Chem. Soc. 2016, 138, 15087-15096. [CrossRef] [PubMed]

21. Freitag, M.; Teuscher, J.; Saygili, Y.; Zhang, X.; Giordano, F.; Liska, P.; Hua, J.; Zakeeruddin, S.M.; Moser, J.E.; Grätzel, M.; et al. Dye-sensitized solar cells for efficient power generation under ambient lighting. Nat. Photonics 2017, 11, 372-378. [CrossRef]

22. Zhang, W.; Wu, Y.; Bahng, H.W.; Cao, Y.; Yi, C.; Saygili, Y.; Luo, J.; Liu, Y.; Kavan, L.; Moser, J.E.; et al. Comprehensive control of voltage loss enables $11.7 \%$ efficient solid-state dye-sensitized solar cells. Energy Environ. Sci. 2018, 1-9. [CrossRef]

23. Flasque, M.; Van Nhien, A.N.; Swiatowska, J.; Seyeux, A.; Davoisne, C.; Sauvage, F. Interface Stability of a $\mathrm{TiO}_{2}$ /3-Methoxypropionitrile-Based Electrolyte: First Evidence for Solid Electrolyte Interphase Formation and Implications. ChemPhysChem 2014, 15, 1-13. [CrossRef] [PubMed]

24. Jones, T.W.; Duffy, N.W.; Wilson, G.J. Efficient all-printable solid-state dye-sensitized solar cell based on a low-resistivity carbon composite counter electrode and highly doped hole transport material. J. Phys. Chem. C 2015, 119, 11410-11418. [CrossRef]

25. Freitag, M.; Daniel, Q.; Pazoki, M.; Sveinbjörnsson, K.; Zhang, J.; Sun, L.; Hagfeldt, A.; Boschloo, G. High-efficiency dye-sensitized solar cells with molecular copper phenanthroline as solid hole conductor. Energy Environ. Sci. 2015, 8, 2634-2637. [CrossRef]

26. Mosconi, E.; Yum, J.-H.; Kessler, F.; Gómez García, C.J.; Zuccaccia, C.; Cinti, A.; Nazeeruddin, M.K.; Grätzel, M.; De Angelis, F. Cobalt Electrolyte/Dye Interactions in Dye-Sensitized Solar Cells: A Combined Computational and Experimental Study. J. Am. Chem. Soc. 2012, 134, 19438-19453. [CrossRef] [PubMed]

27. Yum, J.-H.; Baranoff, E.; Kessler, F.; Moehl, T.; Ahmad, S.; Bessho, T.; Marchioro, A.; Ghadiri, E.; Moser, J.-E.; Yi, C.; et al. A cobalt complex redox shuttle for dye-sensitized solar cells with high open-circuit potentials. Nat. Commun. 2012, 3, 631. [CrossRef] [PubMed]

28. Feldt, S.M.; Lohse, P.W.; Kessler, F.; Nazeeruddin, M.K.; Grätzel, M.; Boschloo, G.; Hagfeldt, A. Regeneration and recombination kinetics in cobalt polypyridine based dye-sensitized solar cells, explained using Marcus theory. Phys. Chem. Chem. Phys. 2013, 15, 7087. [CrossRef] [PubMed]

29. Kivelson, D.; Neiman, R. ESR Studies on the Bonding in Copper Complexes. J. Chem. Phys. 1961, 35, 149-155. [CrossRef]

30. Billig, E.; Williams, R.; Bernal, I.; Waters, J.H.; Gray, H.B. The Electronic Structures of Square-Planar Metal Complexes. II. The Complexes of Maleonitriledithiolate with Copper(II), Nickel(II), Palladium(II), and Platinum(II). Inorg. Chem. 1964, 3, 663-666. [CrossRef]

31. Freitag, M.; Yang, W.; Fredin, L.A.; D’Amario, L.; Karlsson, K.M.; Hagfeldt, A.; Boschloo, G. Supramolecular Hemicage Cobalt Mediators for Dye-Sensitized Solar Cells. ChemPhysChem 2016, 17, 3845-3852. [CrossRef] [PubMed]

32. Jain, S.M.; Qiu, Z.; Häggman, L.; Mirmohades, M.; Johansson, M.B.; Edvinsson, T.; Boschloo, G. Frustrated Lewis pair-mediated recrystallization of $\mathrm{CH}_{3} \mathrm{NH}_{3} \mathrm{PbI}_{3}$ for improved optoelectronic quality and high voltage planar perovskite solar cells. Energy Environ. Sci. 2016, 9, 3770-3782. [CrossRef]

33. Frisch, M.; Trucks, G.W.; Schlegel, H.B.; Scuseria, G.E.; Robb, M.A.; Cheeseman, J.R.; Scalmani, G.; Barone, V.; Petersson, G.A.; Nakatsuji, H.; et al. Gaussian 16; Revision A. 03; Gaussian, Inc.: Wallingford, CT, USA, 2016.

34. Becke, A.D.; Johnson, E.R. A simple effective potential for exchange. J. Chem. Phys. 2006, 124. [CrossRef] [PubMed]

35. Becke, A.D. Density-functional thermochemistry. III. The role of exact exchange. J. Chem. Phys. 1993, 98, 5648-5652. [CrossRef] 
36. Lee, C.; Yang, W.; Parr, R.G. Development of the Colle-Salvetti correlation-energy formula into a functional of the electron density. Phys. Rev. B 1988, 37, 785-789. [CrossRef]

37. Tomasi, J.; Mennucci, B.; Cammi, R. Quantum mechanical continuum solvation models. Chem. Rev. 2005, 105, 2999-3093. [CrossRef] [PubMed]

38. Scalmani, G.; Frisch, M.J.; Mennucci, B.; Tomasi, J.; Cammi, R.; Barone, V. Geometries and properties of excited states in the gas phase and in solution: Theory and application of a time-dependent density functional theory polarizable continuum model. J. Chem. Phys. 2006, 124. [CrossRef] [PubMed]

39. Yang, W.; Hao, Y.; Vlachopoulos, N.; Eriksson, A.I.K.; Boschloo, G. Studies on the Interfacial Electric Field and Stark Effect at the $\mathrm{TiO}_{2}$ /Dye/Electrolyte Interface. J. Phys. Chem. C 2016, 120, 22215-22224. [CrossRef]

40. Cappel, U.B.; Feldt, S.M.; Schöneboom, J.; Hagfeldt, A.; Boschloo, G. The Influence of Local Electric Fields on Photoinduced Absorption in Dye-Sensitized Solar Cells. J. Am. Chem. Soc. 2010, 132, 9096-9101. [CrossRef] [PubMed]

41. Ferdowsi, P.; Saygili, Y.; Zakeeruddin, S.M.; Mokhtari, J.; Grätzel, M.; Hagfeldt, A.; Kavan, L. Alternative bases to 4-tert-butylpyridine for dye-sensitized solar cells employing copper redox mediator. Electrochim. Acta 2018, 265, 194-201. [CrossRef]

42. Kavan, L.; Krysova, H.; Janda, P.; Tarabkova, H.; Saygili, Y.; Freitag, M.; Zakeeruddin, S.M.; Hagfeldt, A.; Grätzel, M. Novel highly active Pt/graphene catalyst for cathodes of $\mathrm{Cu}(\mathrm{II} / \mathrm{I})$-mediated dye-sensitized solar cells. Electrochim. Acta 2017, 251, 167-175. [CrossRef]

43. Cao, Y.; Saygili, Y.; Ummadisingu, A.; Teuscher, J.; Luo, J.; Pellet, N.; Giordano, F.; Zakeeruddin, S.M.; Moser, J.-E.; Freitag, M.; et al. 11\% efficiency solid-state dye-sensitized solar cells with copper(II/I) hole transport materials. Nat. Commun. 2017, 8, 15390. [CrossRef] [PubMed]

44. Yu, Z.; Gorlov, M.; Nissfolk, J.; Boschloo, G.; Kloo, L. Investigation of Iodine Concentration Effects in Electrolytes for Dye-Sensitized Solar Cells. J. Phys. Chem. C 2010, 114, 10612-10620. [CrossRef]

45. Peng, B.; Jungmann, G.; Jäger, C.; Haarer, D.; Schmidt, H.-W.; Thelakkat, M. Systematic investigation of the role of compact $\mathrm{TiO}_{2}$ layer in solid state dye-sensitized $\mathrm{TiO}_{2}$ solar cells. Coord. Chem. Rev. 2004, 248, 1479-1489. [CrossRef]

46. Ellis, H.; Vlachopoulos, N.; Häggman, L.; Perruchot, C.; Jouini, M.; Boschloo, G.; Hagfeldt, A. PEDOT counter electrodes for dye-sensitized solar cells prepared by aqueous micellar electrodeposition. Electrochim. Acta 2013, 107, 45-51. [CrossRef]

47. Solar Spectral Irradiance: Air Mass. Available online: http://rredc.nrel.gov/solar/spectra/am1.5/ (accessed on 28 March 2018). 